\title{
Hareketli Dijital Görüntünün Sanatsal İmge Olarak Estetiği
}

\author{
Tuncay Murat ATAL*
}

Özet

21.yüzyılda güncel sanat, sanal dünyanın insan dokunuşunu içerisinde barındırmaktan uzak olan yapısında inşa edilmektedir. Bir başka tanımlamayla sanat, dijital dünyanın araçları ile kültürel üretimlerin ve tüketimlerin gerçekleştirildiği bir çağın dinamiğinde anlamlandırılmaya çalışılmaktadır. Bu makalenin amacı, gündelik karşılaşmalarda kaçınılmaz bir biçimde tanıklık edilen hareketli dijital görüntülerin sanatsal imge estetiği bağlamında nasıl tanımlanabileceğinin imgebilim alanındaki izlerini saptamaya yönelik bir formül oluşturmaktır. Yöntem olarak güncel üretimleri öncelemek adına en son çalışmaları konu etmektedir. Konunun önemini oluşturan dikkat çekici noktalar dijital teknoloji, sanat ve estetik olduğu içindir ki güncel fikirlerin bugün olanaklı görülen bütün inceleme ve araştırma sonuçları yarının tekinsizliği doğrultusunda yeniden üzerine düşünülmesi gereken doğurgan bir alana dönüşmektedir. Fakat yine de dijital görüntüler, hareketli dijital görüntüler ve aynı zamanda sanatsal imge estetiğinde değerlendirildiklerinden hareketli dijital imgeler olarak adlandırıldıkları makalede, imgeden söz edildiği için, konu genel anlamda imgebilim çerçevesinde değerlendirilmiştir.

Anahtar Kelimeler: Hareketli Dijital Görüntü, İmgebilim, Sanat, Estetik, İmago.

\section{Aesthetics of the Animated Dijital Image as the Art Image}

\section{Abstract}

In the 21st century contemporary art is being created within the virtual universe far from the human touch. In other words, using the tools of the digital world, it is endeavoured to give meaning to art within the dynamics of cultural production and consumption. The aim of this article is to create a discipline to determine the traces of how animated digital images are indispensably witnessed in daily encounters and how they can be defined in scope of artistic image aesthetics of imagology. In its method, it mentions the latest works for the sake of prioritizing contemporary productions. It is because the striking points that form the importance of the subject are digital technology, art and aesthetics that, what appear to be the probable results of all observation and research of contemporary thought turn into a prolific field that is to be ruminated on again in line with tomorrow's uncanny ambiance. Nonetheless it is because the notion of 'image' is discussed in the article that digital images and animated digital images are also evaluated within artistic image aesthetics and in general within the framework of imagology.

Keywords: Animated Digital Image, Imagology, Art, Aesthetics, Imago. 


\section{Giriş}

Günümüzde, dijital teknolojilerin yenilik olarak sunulduğu bir dünyanın içerisinde yaşanılmaktadır. Sanal dünyanın içerisinde yol bulmak için, dijital görüntülerin üreticilerine ve tüketicilerine görsel ve işitsel olarak yeni bir dünyanın dilini dayattı̆̆ kabul edilmelidir. Sadece açma kapama düğmelerinin kolaylığı ile şekillendirildiği düşšunülen yeni dijital teknolojiler, aslında bundan çok daha fazlasını talep etmektedir. Dijital ortamlar, kullanıcılarının programlama dillerini bilmesine gerek olmadığını düşündürse de daha geniş anlamda sosyal yapıların yeniden tanımlanmaları, insan psikolojilerinin teknoloji karşısında alınan pozisyonla tekrar düşünülmesi, insana dair araştırma ve incelemelerin daha insansız gerçekleştirilmesi gereken bir yüzyıla ait bilgiler geliştirilmektedir. Bugün ünlü Silikon Vadisi çalışanları, ekranların karşısında geçirdikleri zamanı kontrol altında tutabilmek için dijital perhiz uygulamaya başlamışlardır. Böylece günün yirmi dört saati maruz kaldıkları ve online ya da offline bir şekilde katılmak zorunda oldukları dijital etkileşime kısmi bir dur deyiş gerçekleşmektedir. Dijital ortamların üreticileri, hafta sonları elektrik sisteminin hiçbir şekilde bulunmadığı ortamları yaşam alanı olarak belirlemekte ve maruz kaldıkları durumu hafifletmeye çalışmaktadırlar. Dijital dünyanın üreticilerinin karşılaştığı bu durum, sadece temel bir etkinin karşısında durmak için yapılan korunma biçiminden ibarettir. Bunun yanı sıra sanal dünyanın görsel ve işitsel olarak karşılaşılan dili, geçmişteki dijital teknolojinin olanakları doğrultusunda yaşamlarını şekillendirmemiş olan insanlardan bambaşka bir zihin yapısında, günümüz insanının bilinç ve bilinçaltı mekanizmalarında yeni bir algı boyutunun temellenmesine neden olmaktadır. Bu türden bir zihin yapısı bütün yaşantıyı dolayısıyla bütün yönleriyle insanı etkilemektedir. Günümüz insanı Descartesci anlamda, 'düşünüyorum öyleyse varım'dan ${ }^{1}$ önce, 'ekran karşısındayım' ile ‘öyleyse var'dır.

Bu türden bir insan olma durumu ve 21. yüzyıl insanının varoluşu, edebi hâlini Viktor Pelevin'in eserlerinde ${ }^{2}$ bulmaktadır. Pelevin'in düşünce dünyasından örnekle, sözü sözüne güncel mitoloji incelendiğinde şu şekilde bir durum tespiti ile karşılaşırız:
İlerleme bize türlü biçim ve boyutlarda işıltıı ekranlar getirdi. Ama eğer içerik ve yapı açısından bu uç noktadaki parlaklığı çözümlemeye kalkarsak, er ya da geç yolculuğumuzun çıkış noktasını -asıl miti- anlarız. Yeni bir kılığa girmiş olabilir, fakat özü değişmemiştir. Durmaksızın geçmişe savrulup savrulmadığımızı ya da acımasızca geleceğe sürüklenip sürüklenmediğimizi tartışabiliriz, ama asında yerimizden bile kıpırdamamışızdır (Pelevin, 2007: 10).

Yazar, günümüz mitolojisini oluşturduğu 'Dehşet Miğferi’ adı kitabında, Antik Yunan mitolojisindeki klasik bir kahramanlık miti olan Theseus ve Minotauros mitinden yola çıkılarak bu kadim hikayeyi günümüz iletişim biçimlerinden biri olan internet ortamına uyarlamıştır. Bir otel odasına kapatılmış, nerede olduklarını, oradan nasıl çıkacaklarını bilemeyen sekiz genç, birbirleriyle internetin sohbet odalarından haberleşerek bu absürt durumdan kurtulmanın yollarını aramaktadırlar. Ancak orada onlara yardım edecek bir Theseus yoktur. Pelevin'in edebiyat eserinde yarattığı karakterlerin benzer yansımaları, günümüz insanının ekranların karşısındaki konumunu gözler önüne sermektedir. ${ }^{3}$ Sanal dünyanın küresel yapıdaki gerçeklik dışı dünyasındaki iletişim olanaklarının kullanıcıları, Dünya Çapındaki Ağ’ın (World Wide Web) ${ }^{4}$ bilgisayar kontrollü yani sibernetik mekânının koordinatları üzerinde varolmaya çalışmaktadır. Fakat, bunun yanı sıra küreselleştiği kabul edilen ancak nasıl başedileceğine dair çaresizlik hissettiren günümüz dünyasının en önde gelen düşünürlerinden biri olan Zygmunt Bauman'a göre (2012: 31), "Buluşma yerleri aynı zamanda normların yaratıldığ yerlerdir; adalet böylelikle sağlanabilir ve yatay olarak dağıtılabilir, böylece konuşmacılar bir cemaat olarak yeniden biçimlenir, ortak değerlendirme ölçütlerine göre ayrılır ve bütünleşirler." Böylece düşünür, kamusal mekânı kalmamış yörelerin ve üstelik bunların başka veçheleri şeklinde oluşmuş bulunan küreselleşmiş dünyanın yeni teknolojili dijital alanlarının, normların tartışılmasına, değerlere karşı çıkılmasına, karşılaştırılıp müzakere edilmesine pek şans tanımadığından bahsetmektedir (Zygmunt, 2012: 32). Dolayısıyla doğru ve yanlış, güzel ve çirkin, uygun ve uygunsuz, faydalı ve faydasız gibi hükümlerin ancak yükseklerden ve sadece tepeden inme 
bir şekilde gerçekleşebilir olduğuna dikkat çekmektedir. Bu, hükümlerin sorgulanamazlığı söz konusu olan bir dünya algısıdır. Soruların oluşturulabileceği mekânların yetersizliği söz konusudur. Bu nedenledir ki yargıçlara hiçbir soru anlamlı bir şekilde sorulamaz. Bauman tepede oluşan yapının toplumsal yapıyla bağlantılarının kopuşunun altını çizmektedir. Bauman'a göre (2012: 32), “... yargıçlar adres -elektronik posta adresi bilebırakmamıştır ve hiç kimse nerede oturduklarından emin olamaz. Yerel kanaat önderlerine yer kalmadığ gibi, 'yerel kanaat' diye bir şeye de yer kalmamıştır.". Bu düşünceleri ile Bauman'ın terminolojisi, bir grup insanın, bütün dünyanın yaşamsal dinamiklerini ele geçirdiği tüketim dünyasının ve 21. yüzyılın teknolojik mekânının gerçekliğini tanımlamaktadır.

Pelevin'in yarattığı karakterlerin doğrultusunda insan tanımları ve Bauman'ın düşünceleri eşliğinde güncel mekânın koordinatlarının tespit edilmesinden hemen sonra, gerçekte bu yapının içerisinde kendisini konumlandırmaya çalışan günümüz insanının psikolojik durumunu nasıl inşa ettiği incelenmek istendiğinde, Rainer Funk'un tespitleriyle karşılaşılmaktadır. Erich Fromm'un öğrencisi olan psikanalist Funk'un, günümüz toplumunda insanın bütün karakter özellikleriyle masaya yatırıldığı kitabındaki 'postmodern ben-odaklılı' olarak adlandırılmış olan psikolojik durumunun oluşumunda önemli etkenlerinden biri, teknolojik ilerlemedir. Dijitalleşme ve medyadaki teknolojik yeniliklerin yol açtığı ve açmaya devam ettiği köklü değişimlerin toplumsal yaşam pratiği üzerindeki etkileri konu edilerek oluşturulan bu teknolojik 'gelişme' doğrultusunda Funk (2009: 27), postmodern ben-odaklı insan karakterinin psikanalizini gerçekleştirmektedir:

İnsan dört duvarın içinden çok, sanal dünyalarda kendini evinde hissetmektedir; hızlı trenlerde gözünü monitörlere dikmek pencereden bakmaktan daha çekicidir. 'Siber dünya' 'in'dir, çünkü yaratılan dünya reel gerçeklikten daha gerçek ve daha hoştur. İnsanın kendisi için yarattığı bir dünyanın ve dünya algısının tercih edilmesi haplara, halüsinojen manipülasyonlara ve maddelere duyulan hayranlığı da açıklamaktadır (Funk, 2009: 34).

Sonuç olarak Funk'un düşünsel pratiği, kendisinin de belirttiği gibi (2009: 34), sonsuz sayıda örneklerle çoğaltılabilmekte ve yaşamın siyaset dâhil neredeyse her alanına genellenebilmektedir. Funk'un düşüncesi takip edildiğinde, günümüz insanının dijital dünya içerisinde nasıl kolayca kendisini kandırabiliyor olmasına dair bilgi açığa çıkmaktadır. Bu düşünceler doğrultusunda ilerlendiğindeyse hareketli dijital görüntüler dünyasının dinamikleri, hayatın içerisindeki gerçekleşen trajedilerden uzak bir şekilde; beğenmek ve beğenmemek (en bildik sosyal paylaşım ağlarından biri olan Facebook'daki ifade buluşuyla like), dolaşıma sokmak veya dolaşımda olmak (yine Facebook'daki hâliyle share) şeklindeki yorumlamalar sınırlılığında gerçekleştirilmektedir. Sanal dünyanın bu türden işleyişi, çağın başlıca fenomenini gözler önüne sermektedir; günümüzde ölüm kalım savaşları ve başka diyarlarda yaşanan insanlık dışı olaylar izleyiciler tarafından ekrandan yansıyan hareketli dijital imgeler olarak algılanmakta bu nedenle olayların bütün sahiciliği yansıtan haberler insanı kendine yabancılaştıran bir soğukkanlılıkla seyredilmektedir. Böylece Funk'un postmodern insan olarak ortaya koyduğu insan tarifinin psikanalizi takip edildiğinde yine düşünürün tanımlamasından yola çıkılarak çağdaş pazar ekonomisi ve başarı reçetesi ile karşılaşılmaktadır. Bu yapı, özlemi duyulan dünyalar üretmek üzerinden işlerliğini kazanmaktadır. Funk’a göre (2009: 34-35), “Bu pazarlama stratejisi insanın kendisine ilişkin imgesine de uygulanmaktadır. Herkes kendisini olduğu gibi algılamak yerine, özlemini duyduğu imgesiyle birlikte özdeşleşerek kendi gerçekliğini yeniden üretebilmektedir” ya da bir başka perspektiften bakıldığında kendisini üretememektedir. İnsan diğer bütün zamanlardaki hâliyle, ancak ve ancak kendisini olduğu gibi algılayabileceği durumlar ve mekânlar doğrultusunda yol alırsa, kendisini hakikat boyutunda var edebilmektedir. Günümüz insanı için varoluşuna ait durum, bahsi geçen şekilde gerçekleşebilecektir. Bu nedenle günümüzde insanın ifade buluşunun kavramsal yapısı, sıkıntılı bir varoluş biçimini göstermektedir.

Günümüz görüntü üretimini konu alan bu makale, çıkış yolunu dijital görüntülerin inceleme ve araştırmasındaki tanımların tartışmaya açılması olarak belirlemiştir. İmgebilim alanında saptamalara yönelik bir 
iz sürme söz konusu olduğundan dolayı günümüz insanının sosyalbilimsel, psikanalitik ve felsefik varoluşunun sıkıntılı çıkmazı yol gösterici olacaktır. Bir arada yaşanması zorunlu hâle gelen dijital görüntüler ve sesler dünyasının içerisinde yol bulmaya çalışılan günümüzde, sanal dünyaya ait tanımların belirlenmesi, durumun gerekliliği açısından yöntem olarak kullanılmıştır. Konunun imkansızlığını sınırlandırmak için bu makalede, dijital sesler dünyası ile etkileşim kapsamlı bir başka çalışmanın konusu olarak değerlendirmiş̧ir. Bu nedenle, sadece görüntüler için gerçekleştirilecek olan tanımlamalar hedeflenmektedir. Hareketli dijital görüntüler sanat, estetik ve etik tartışmalarla evrilerek, hareketli dijital imge olma bağlamında imgebilim alanında bir düşünsel pratik içerisine yerleştirilecektir.

\section{Hareketli Dijital Görsel, Görüntü, İmge}

Sanal dünyanın araçlarından yansıyan dijital görüntülerle, temelde görseller olarak karşıllaşılmaktadır. Bir başka ifadeyle sonsuz, sınırsız sayıda görselin göze geliş biçimiyle içli dışlı bir etkileşim söz konusudur. Bütün bu görseller dijital görüntüler dünyasını yaratır. Dijital görüntülerin sanal dünya içerisinde hareketliliği konusuna gelindiğindeyse çoğu zaman dijital görüntüler kendi içinde hareketlidirler ve hareketli dijital görüntüler olarak tanımlanmaları gerekmektedir. Aynı zamanda kendi içinde durağan ya da hareketli olan dijital görüntüler sanal dünyanın içerisinde oluşturuldukları an itibariyle sonsuz ve sınırsız bir ağın içerisinde hareket etmeye başlarlar. Bundan dolayı, durağan ya da hareketli olması farketmeyecek bir biçimde sanal gerçekliğin en başta gelen özelliği, oluşan görüntülerin sanal dünyadaki dolaşımı potansiyeli doğrultusunda varoluşlarıdır.

Hareketli dijital görüntülerin bu aşamasında göze geliş biçimlerinin belirlendiği ve şu ya da bu şekilde izleyici ile temas geliştirdikleri süreçte, hareketli dijital görüntüden hareketli dijital imgeye geçişin gerçekleşmiş olduğu bir imgeleşme söz konusudur. Hareketli dijital imgeler, sibernetik ağda yol alırken çıkış noktası buldukları herhangi bir ekran üzerinden varoluş biçimlerini görünür kılmaktadır. Hareketli dijital imgelerin kendi içlerindeki ve sanal ağdaki hareketinin, antik çağlardan beri insanoğlunun hareket kavramının ve bu konunun düşünsel pratiği kapsamındaki fikirlerinin bir uzantısı olup olmadığının tespiti gerekmektedir.

Dijital dünyanın içerisindeki hareket kavramının, insanoğlunun antikitede oluşturduğu hareket kavramı ile bağının, sosyolog ve düşünür Ulus Baker’in yorumlarıyla incelendiğinde Baker, antik çağda Yunanlıların düşüncesinde önemli bir noktaya değinmektedir; physis. Baker'in deyişiyle physis, akış yani varlıkların akıyor zamanın ise bu akışın ilkesine boyun eğiyor oluşudur. Bu düşünce çerçevesinde zaman, tanrısal bir akışın dış görünümü konumundadır. Açıklamaları doğrultusunda Baker, hareket kavramına denk düşen akış terimi içerisinde varlıkların ne yaptığını sormaktadır. Baker tarafından, Antik Yunan'da varlıkların, 'aşkın formların ardışıklığı'ndan oluştuklarının düşünüldüğü aktarılmaktadır. Yani varlıklar bir nevi 'poz verirler' insanlara. Doğa, izleyenlerine duruşlar, duruş noktaları vermektedir. "İdeal ayrıcalıklı anları vardır sözgelimi bir hareketin, bir mekanik hareketin. Bu ayrıcalıklı anların 'en' ayrıcalıklı olanı da vardır, buna telos diyorlar, yani hedef, erek; bir formun aktüelleşmesi, etkinleşmesi, gerçekleşmesi.” (Baker, 2015: 22). Böylece Baker, Aristoteles'in bir ebedi formdan başka bir ebedi forma geçiş olan ünlü formlar öğretisinin en temelindeki yalın anlamını açıklamaktadır. Baker'in oldukça sade ifadesiyle (2015: 23) "Dolayısıyla, bütün Yunan estetik anlayışı da -ama müziği, dansı nasıl pratik ettikleri, nasıl bir mimarileri olduğu da dahil olmak üzere- bir formlar öğretisidir. (...) Bu formlar düşüncesi, bu biçimler düşüncesi asla bizim modern anlamdaki biçimcilikle alakası olan bir şey değil."dir. Modern zamanlardaki (üstelik modernizm için Rönesans milat olarak alındığında) sanat ve estetik biliminin tarihsel sürecinde yaşanan düşünsel kırılmaların etkisinden dolayı, antikitedeki fikir dünyası ile günümüzün, daha net tarif ile çağımızın düşüncelerini farklııkları açısından yeniden değerlendirmek yerinde olacaktır. Bu türden bir değerlendirmenin düzlemini, Batılı tarihsel dizgede kurumları ve kavramları oluşmuş sanat ve estetik alanında bulmaktan ziyade, imgebilim üzerinden gerçekleştirilecek tartışma alanları daha yerinde sonuçlar doğuracaktır.

Hareketli dijital görüntü ve imge ile hareketli dijital görsel tanımlamaları kullanılırken ünlü Fransız filozof 
Jacques Rancière'in Görüntülerin Yazgısı metninde açıklığa kavuşturduğu üzere; "birçok çağdaş yazar bir Öteki'ye göndermede bulunan Görüntü/İmge ile kendisinden başka hiçbir şeye göndermede bulunmayan Görsel'i karşıllaştırmaktadır." (Rancière, 2008: 4). Sanal dünyadaki hareketli dolaşımlarındaki bütün görüntüler, özellikle estetik ve etik değerlendirmeler içerisinde çerçevelendiklerinde ve sanat öncesi ya da sanat sonrası sınıflandırmaları doğrultusunda ele alındıklarında görsel olarak kalmayacaklar, üstelik görüntü olmaktan öteye taşınacaklardır. Makalede incelenecek ve araştırılacak olan hareketli dijital görüntüler sanal dünyada gerçekleştirilmiş hareketli dijital görüntüler olmalarına rağmen seçilmişlikleri nedeniyle imgeler dünyasının dinamiklerinden beslenmektedirler. Bu yüzden hareketli dijital imgeler adlandırmasıyla değerlendirileceklerdir.

Yine Görüntülerin Yazgısı metninde Rancière 'görsel'i küçümseyen düşünürlerin en sık verdikleri yanıta değinmekte ve çok sayıda yapıtlar ile televizyonda yayınlanan popüler programları karşılaştırmaktadır; "Televizyon görüntüsünün -bizzat doğası gereğiötekisi yoktur, zira kendi ışığını kendinde taşır; oysa sinematografik görüntü ışığını bir dış kaynaktan alır." (Rancière, 2008: 4). Düşünür, bu yanıt üzerinden değerlendirmelerini gerçekleştirirken görsel/görüntü/ imge ayrımında, sinema perdesiyle televizyon ekranının ayrıldığı ya da birleştiği noktaların içsel olarak farklı olan şeyden kaynaklandığını belirtmektedir. Bunun ise üreten kişilerin performansları olduğundan bahseder; "Demek ki, film görüntüsü ve televizyon yayını, başkalık ile özdeşliğin karşıt olması gibi karşıt değildirler. Televizyon yayınının da kendi ötekisi vardır: platodaki gerçek performans. Ve sinema da kamera karşısında gerçekleştirilen performansı yeniden üretmektedir." (Rancière, 2008: 9). Bunun yanı sıra düşüncelerinde sanat alanına ait imgelerin rejiminden bahsederek sinematografik görüntüler ile televizyon görüntülerinin tanımlanmasına açılımlar sağlamaktadır. Rancière düşüncesinin açılımları ve günümüzdeki sanatsal tartışmalar doğrultusunda makalenin genelinde kullanılan güncel görüntüler, hareketli dijital görüntüler olmalarından öteye hareketli dijital imgeler hâline geçmiştirler. Hareketli dijital görüntüler, sanatsal imge olarak estetik ve etik tartışmaların içerisinde değerlendirildikleri andan itibaren imgeleşme süreci yaşamaktadır ve hareketli dijital imgeler olarak adlandırılmaları, imgebilim içerisinden bir bakışla incelenip araştırılmaları daha doğru olacaktır. Böylece neyin izlerini taşıyıp, nasıl bir şeyin tam zıttı olarak kendilerini bakışa sundukları ve nasıl bir bilgi boyutunun göze geliş hâlini yansıttıkları netleşecektir.

\section{Sanat, Estetik, İmgebilim}

Hareketli dijitalgörüntülerin imgeleşmesinin tanımlanmaya çalışıldığı süreçte, seçilmiş ve değerlendirilme kapsamına alınmış olmalarından kaynaklı hareketli dijital imgeler adlandırılması ile devam edilecektir. Hareketli dijital imgelerin imgebilimsel varoluşuna açıklık getirmek için imge kavramından devam edildiğinde imge üst başlı̆̆ı, sanat öncesi ve sanat sonrası olarak ayrıştırılacaktır. Bu tanımlama, Batılı sanat tarihindeki Rönesans ile başlayan aydınlanmacı modernist dönemi milat olarak kabul eder. Tanımın gerekliliği, analog fotoğraf karelerinin sanat öncesi imgelerin ve hareketli dijital görüntülerin ise sanat sonrası imgelerin hâlinden beslenen kaynağını belirlemek içindir. Nedeni, analog fotoğraf kareleri dâhil olmak üzere sanat öncesi imgelerin el ile şekillendirilmesindeki süreç ve bu sürecin duyulara hitap eden varlık alanından kaynaklanmaktadır.

Sanat öncesi imgeler, dokunuşun izini taşırlar. Sanat sonrası imgeler ise duyumsal bir estetik anlayışının yani Platoncu bir ifadeyle duyular dünyasının izlerinden uzak bir şekilde üretilmişlerdir. İdeal bir ifade biçimini öngördükleri için sanatsaldırlar. Böylece antik zamanların el üretiminin dışında, 'tekniğin olanakları doğrultusunda çoğaltılmış' imgelerin dünyasına aittirler. Estetik değerlendirme kategorileri güzel/çirkin, iyi/kötü gibi ikili karşıtlıklarla belirlenmektedir. Sanat öncesi imgeler ise Antik Yunan dilinde aisthênesthai duygularla algılamayı ve hissetmeyi ifade eden ve beş duyuya ilişkin her tür algıyı kapsamaktadır. Yazınbilimci ve sanat kuramcısı Zeynep Sayın'ın altını çizerek belirttiği gibi, aisthesis sözcüğü 18. yüzyıl ortasında yeni bir kavrama evrilmiştir ve Batı modernizm süreci içinde güzelliğin özerk bilimine dönüştürülmüştür. "Güzellik yasasının uygulamalı öğretisidir estetik; bundan böyle bir nesnenin "estetik" olduğu söylendiği zaman, onun artık güzel ve beğeniye 
uygun bir nesne olduğu ifade edilmiş olacaktır." (Sayın, 2000: 164). Bu konu dâhilinde hareketli dijital imgelerin beş duyuya ait olup olmadığı, duyularla algılanabilirliği tartışılacaktır. Dolayısıyla hareketli dijital imgelerin, güzel ya da çirkin, iyi ya da kötü değerlendirmelerinin dışında duyumsanabilirliği ile göze geliş yeri ve kendini bakışa sunuştaki sanat sonrası imgelerin örgütlenme biçimindeki dinamiklerden beslenmesi ilgi çekicidir. Bu türden bir ilgi çekicilik, makalenin özelindeki önemli tespitlerden biridir.

Bütün bu terimlerin ikili tanımlamaları, karşıtlıklarının devinimleri içerisinde var olurken kavram zıtlıklarının etkileşime girdiği bir varoluş biçimi söz konusudur. Özetle imgeler, kendi hâlleriyle birer benzemezliktir. Böylece görüntü/imge görülebilir olanın tekelinde değildir. $\mathrm{Bu}$ türden bir varoluş imgenin şu şekilde algılanmasını sağlamaktadır; "Öyle bir görülebilir vardır ki görüntü/ imge oluşturmaz; öyle görüntüler/imgeler vardır ki tümüyle sözcüklerden oluşmuştur." (Rancière, 2008: 10). Rancière, burada, güncel olan görüntü rejimi'nden, söylenebilir ve görülebilir olanın ilişkiye sokulduğu alandan bahsetmektedir. Bu ilişkilenme biçiminde söylenebilir ve görülebilir olanın hem benzerliğinden hem de benzemezliğinden yola çıkarak aslında bu iki terimin maddi olarak bulunmasının hiçbir şekilde şart olmadığını açıklığa kavuşturmaktadır. Bu düşünceler doğrultusunda Zeynep Sayın'ın İmgenin Pornografisi adlı kitabındaki imgenin varoluşu üzerinden yürüttüğg̈u tartışmaları referans alarak, 19. yüzyılda Avrupa imgelemini sarsan fotoğraf, bedensel dokunuşun izini taşıyan bir imgedir (Sayın, 2003: 77). Dolayısıyla sanat öncesi imgenin hâlinden beslenmektedir. Fakat hareketli dijital imgelerin oluşturduğu varlık alanı, Batı sanat tarihindeki estetik kırılmalardan sonraya tarihlenmektedir. Başka bir şekilde ifade edildiğinde, hareketli dijital imgelerin varlık alanı, sanat sonrası imgenin hâlinden yol almaktadır. Bu nedenle, sanatsal imgenin estetiğinden varolmaya çalışmaktadır. Fotoğraf izin bıraktığı boşluğu göstermeye ya da daha doğru bir ifadeyle gösterememeye çalışırken, hareketli dijital imgeler izi temsil etmeye yeltenmektedir. Hareketli dijital imgeler sanatın estetik dinamiklerinin yolundan iz bulmaya çalışmaktadır ve pornografikleşmektedir.

Eğer söylenene somutluk getirmek gerekirse bu, bir
Amerikan dolarının ya da Saddam Hüseyin imgesi taşıyan bir kol saatinin, Plinius'un karşı çıkacağı türden bir imge olduğu anlamına gelir. Bunların her birinde bir benzeşim ve tekabüliyet önermesi bulunmaktadır. Hepsi de siyasal iktidarın temsiline bu nedenle dönüşebilmekte, bilgi ile iktidarı varlıkta buluşturduklarını iddia etmektedirler (Sayın, 2003: 76).

Hareketli dijital imgelerin tekinsiz yapısı, sanatsal imgelerin estetik çatı altında bilgi ve iktidarın hizmetinin görüntüsüne dönüşmesindendir. Aynı şekilde, sanatsal imgelerin karanlık noktası olan bilgi boyutunu taşıyarak çok kolay manipüle edilebilmektedirler ve propaganda aracı hâline getirilebilmektedirler. Neticede bu hâl, dokunuşun izini barındırmaktan yoksun olduğu ve sanat sonrası imgenin hâlinden beslendiği için, haysiyetsiz ve zelildir. Daha kapsayıcı bir tanımlamayla hareketli dijital imgeleri pornografikleştirmektedir.

\section{İmago}

İmgebilimin inceleme ve araştırma yöntemleri doğrultusunda ortaya çıkan bilgi ile hareket kavramı için, hareketli imgenin tekniğin olanaklarından da önce göze gelen, dolaşımda olan imgenin gerçekliğini temsil etmekte olduğu söylenmelidir. Bunun başlıca nedeni, insanın zihin yapısı itibariyle düşünme biçiminin, bilinç ve bilinçaltının, dolayısıyla tahayyül etme sürecinin, rüya görmesindeki dizgenin, hareketli bir algı boyutuna denk düşmesidir. Temelde bu, etrafımızda olan biten her şeyin hareketli varoluşu ile açıklanabilir. Bu türden bir hareketli imgeler dünyasından algılanıp üretime dönüştürülen görüntüler, 18. yüzyıl sanat tanımlaması içinde kendilerini daha kısmi mekânların içinde yani müzeler, sergi salonları vb. yerlerde konumlandırmaktadır. Sanat algısı ile gerçekleşmiş olan imgenin sanatsal mekânların içerisindeki sergilenme biçimleri imgenin varlığında sınıflandırmaya denk düştüğü gibi aynı zamanda sanat öncesi imgelerin varlığının sınırlanmasına neden olmuştur.

Bunun yanısıra, teknik olanaklarlageliştirilmişve sanal dünyanın sistemi içerisinde oluşturulmuş hareketli dijital imge, günümüz insanının sanat algısını özgürleştirmiş olan görüntülerden oluşmuştur. Burada sözü geçen özgürleşme, sanatın kendini gerçekleştirdiği mekânların farklı imkânlar doğrultusunda modern zamanların sergi mekânlarından 
başkalaşarak hayatın içinde karşımıza çıkmasından kaynaklanmaktadır. Özgürleşmenin yanı sıra bir o kadar da manipüle edilmiş ticari, siyasi, propaganda aracı imgelerden bahsetmeden özgürleştirici dijital imgelerden bahsetmek eksik kalacaktır.

Sözü geçen iki süreçte de belirleyici noktalardan bir tanesi, seyirci karşısında imgenin kendini bakışa sunarken oluşturduğu örgütlenme biçimidir. Doğu'da insan eliyle oluşturulduğu bilgisini taşıyan ve bakışa sunulduğunda kendini görülmek üzere dayatmayan imgeler geleneği söz konusudur. Ancak Avrupa'da siniflandırmaların gerçekleştiği Rönesans ile başlayan ve Modernizm ile geliştirilen, Batılı görmeye dayalı temsil sistemi keşifler ile yeni coğrafyalara açılan süreç doğrultusunda etki alanını genişletmiştir. Sanat ve bilim tanımlarının oluşturulduğu dönemlerde, sınıflandırma yöntemi doğal olarak ayrıştırmayı da beraberinde getirmiştir. Bu türden ayrıştırmacı bir yöntem sanat ile hayat arasındaki bağlantıların kopuşunda da kendini göstermiştir. Dolayısıyla Batılı temsil biçimlerinde sanat ve hayatın birbirinden koptuğu bir sürece tanıklık edilmektedir.

Hareketli dijital görüntüler günümüz insanını, yeni bir sanatsal üretim şeklini gerçekleştirme ve geçmiştekinden farklı bir izleme yöntemine yöneltmektedir. Bu türden güncel sanat üretimleri, hâlen beyaz küp galerilerin steril alanında sergileniyor olsa dahi sanatsal imgenin yaşamla kurduğu ilişkileri farklılaştıran ve daha geniş algılama perspektiflerini izleyiciye önceleyen bir üretim ve tüketim biçimini gerçekleştirmektedir. İzleyicinin gözünün oburluğunu tatmin etmeye çalışmak kelimenin birinci anlamıyla doygunluktan değil, oburluktan bahsedildiğinden dolayı zordur. İzleyici/alımlayıcı artık sosyal medyanın sonsuz ve sınırsız alanında anlamlandırmaya çalıştığı imgelerle etkileşim hâlindedir.

Bu türden bir sınırsızlık içeren hareketli dijital görüntüler alanındaki inceleme ve araştırma çalışmalarına bir başlangıç noktası belirlenmek istendiğinde, Tate Müzesi'nin ilginç bir etkinliğiyle karşılaşılmaktadır. ‘1840's GIF Party' (1840lar GIF Partisi) adlı etkinlik başvuruları Tate Müzesi'nin sponsorluğunda ve 17 Ocak - 7 Şubat 2014 tarihleri arasında gerçekleşmiştir. Bütün internet kullanıcılarının katılımına açık olan 1840’lar GIF
Partisi'nin amacı hareketli dijital görüntülerin bir depolama türü olan GIF $^{5}$ formatında hazırlanarak, 1840'lara ait Tate Müzesi koleksiyonunun yine sözü geçen koleksiyondaki orijinal başyapitlarla bir arada, 1840'lar Odası'nda sergilenmesidir (Resim 1-2). ${ }^{6}$ Hareketli dijital görüntüler ile yapılan üretimler artık günümüzde dünyanın en prestijli müzelerinde yer bulmaktadır. Bu durum, hareketli dijital görüntünün sanatsal anlamda en tanımlanabilir hâlini gözler önüne sermektedir. Fakat bütün makale boyunca altı çizilerek belirtildiği gibi sanal dünyanın insan yaşantısını kuşatan gerçekliğiyle karşı karşıya kalınmaktadır. Bir çıkış yolu bulmak ve anlamlandırmak için sanatın içerisindeki hareketli dijital görüntülerin yeri değerlendirilebilir fakat asıl sorun bütün kapsamıla hareketli dijital imgelerin insan yaşantısındaki kapladığı alanı tespit etmektir.

Gelinen noktada sanatın içerisinde yol bulmaya çalışmak ve sanat müzelerinin sponsorluğundaki etkinlikleri konu etmek bir yana aslında hareketli dijital imgelerin, kendilerini bakışa sunma durumundaki örgütlenme biçiminin daha önemli açılımlarını sorun etmek üzerinden gerçekleştirilecek bilgi boyutu üzerine düşünmek gerekecektir.

Bir müzenin sergi salonunda karşılaşılacak olan hareketli dijital imgeler, bakmak ve görmek konuları ile ilgili geleneksel öğretilerin öngördükleri şekillerde algılanmaktadırlar. Bunun yanı sıra sosyal medyada koşulsuz bir şekilde bütün internet kullanıcılarının ortak paylaşım alanı olarak yapılandırılmış sitelerde (Facebook, Instagram, Flickr vb.) karşılaşılan görüntüler, imgeleşme boyutunu gerçekleştirmeden direkt bakışa sunulmuşlardır. Dolayısıyla varoluşları tekinsiz bir algılama boyutunu (algılayamama ve anlamlandıramama) barındırmaktadır. Genelde sanat olduklarını iddia etmektedir ve güzel/ çirkin, iyi/kötü gibi kavram karşıtlıkları içerisinde değerlendirilmektedir. Herkesin kullanımına açık ve anonim oluşlarından kaynaklı internet ortamında dolaşıma girdikleri an istenildiği gibi kullanılabilmektedir. Bu durum kolayca bağlamından koparılabilmelerini ve istenilen şekilde manipüle edilmelerini sağlamaktadır. Ancak imgenin varoluşu kapsamında değerlendirilecek olan herhangi bir görüntü, imgeleşme sürecine imago'ya ${ }^{7}$ ait bilgi boyutu ile başlayacaktır. Böylece tarihsel anlamdaki 
düz çizgisel mantıkta değil geçmişten gelen hakiki izleri doğrultusunda değerlendirilebilecektir.

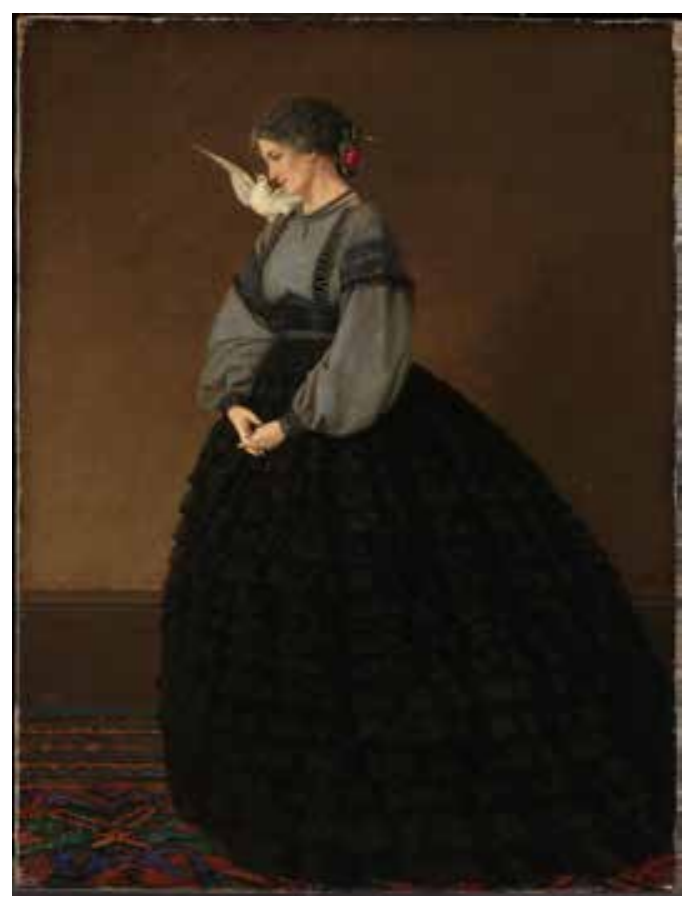

Resim 1. John Brett, 'Lady with a Dove: Madame Loeser' (Güvercinli Kadın: Madame Loeser), 1864, Tate Müzesi, Londra, İngiltere.

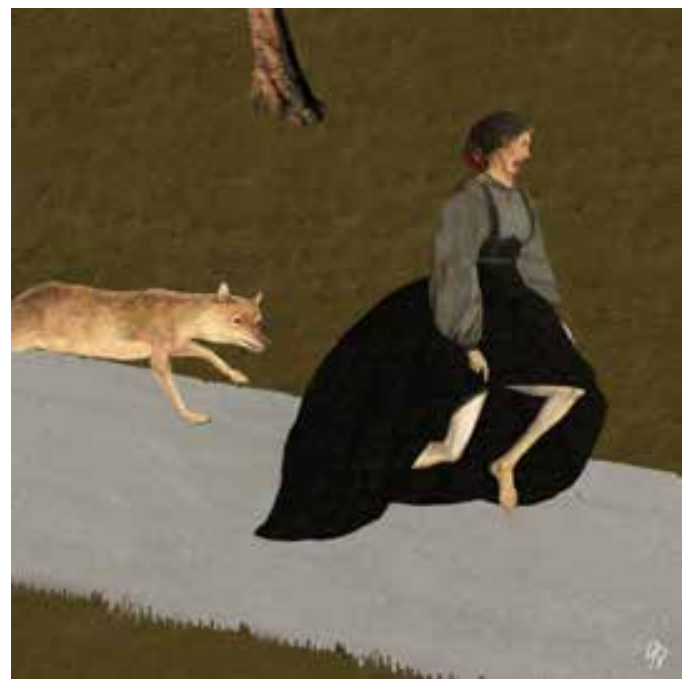

Resim 2. Tate Müzesi'nde 7 Şubat 2014'de bir müze sergisi olarak kurgulanan etkinlikten bir fotoğraf. Resim 1'deki John Brett'in ‘Lady with a Dove: Madame Loeser’ (Güvercinli Kadın: Madame Loeser), adlı tablosunun James Kerr tarafından yapılmış GIF formatındaki replikası.

\section{Sonuç}

Hareketli dijital imgelerin varlık alanı, sanatsal imgenin estetik yapısından beslenmeye çalıştığından dolayı güncel sanat içerisindeki özgürlükçü ifade bulma biçimleri ile çelişmektedir. Güncel sanatın olanaklar alanı olarak tanımlanabilecek yenilikçi tavrı ile söz konusu bağlamda çatışkı gerçekleşmektedir. Buna ek olarak, sanatsal estetik kriterler kapsamında değerlendirmek üzere kendisini örgütleyen hareketli dijital imge bulmak zordur. Sanat içerisinden genel anlamda yol alındı̆̆ında, teknolojiyi yaratıc bir kaynak olarak kullanan hareketli dijital imgelerin varlık alanları, internetin sonsuz ve sınırsız sanal gerçekliğinin küçük bir yüzdesinde gerçekleştirilmektedir. Söylenenin en somut hâli, sanal ortamlar ya da günümüz dijital sosyal medyası olarak tabir edilen buluşma mekânlarının daha çok anonim dijital görüntülerden besleniyor olmasıyla örneklendirilebilmektedir. Artık günümüzde edebi bir metnin sadece bir cümlesini, modern zamanların klasik sanat eserlerinin varoluşundan beslenen bir başyapıtın tek bir parçasından oluşan dijital fotoğrafı ile birleşmiş bir şekilde, üstelik bütün hayatın anlamını ifade eder bir biçimde görmek mümkündür. Hatta her internet kullanıcısı bu türden bir kolaj görseli kendine mâl ederek paylaşma ve dolaşıma sokma hakkını kendisinde bulmaktadır. Nereden kaynaklandığı belirsiz hareketli dijital imgelerin, nereye gidecekleri de tayin edilememektedir.

Sözün özü, günümüzde insanların üretim ve tüketim biçimleri yeni teknolojinin olanaklar alanında gerçekleşebilir. Yeni olanın bilgi boyutu her zaman doğru bir şekilde hayatın içerisinde şekil bulması açısından düşünülmemelidir. Güncel olanın parıltısı, gerçeklik boyutu her daim hakikati barındırmak durumunda değildir. Hareketli dijital imgeler, sahte bir güzelliğin yanılsamasını sunma konusu dikkate alınarak titizlikle tespit edilmelidir. Sadece düz çizgisel bir tarih anlayışının güzel/çirkin, iyi/ kötü, doğru/yanlış yorumlama pratiğindeki buldukları yer üzerinden değil kapsamlı imgebilim araştırmaları eşliğinde incelenmelidir. Böylece hareketli dijital imgelerin haysiyetinden ya da zelil oluşlarından, sanatın günümüze kadar oluşturduğu iktidarın taşıyıcısı olduklarını iddia ettiklerinden dolayı propaganda aracı 
konumuna dönüştükleri ve kelimenin birinci anlamılla her çeşit siyasi erkin iktidar taşıyıcısı olarak kullanıldıkları hâlleriyle pornografik varoluşlarından bahsedilebilecekleri tartışma alanları ortaya çıkacaktır. Bu türden inceleme ve araştırmalar, hareketli dijital imgelerin estetik ve etik anlamlarını zenginleştirecektir. Hayatın içerisinde daha yaşamsal ve daha duyumsanabilir kullanımda olmalarını sağlayacaktır.

\section{Notlar}

1 Cogito ergo sum.

2 Başlıca eserleri arasında Böceklerin Yaşamı (2001), Buda'nın Serçe Parmağı (2002), Omon Ra (2003), Homo Zapiens (2004), Dehşet Miğferi (2007), Verita (2015) bulunmaktadır.

3 Viktor Pelevin özellikle Dehşet Miğferi adlı kitabını mitoloji olarak nitelendirmektedir ve 21.yy.'ın mitolojisini yazmaktadır. Karakterlerin diyaloglarından oluşan bu absürt denemenin karakterleri isimleri ile de oldukça ilginçtir. Kitapta, “Organisma(:-”, “UGLI 666”, "Nutscracker”, "IsoldA”, “Monstradamus” v.b. oluşturulmuş karakter isimleri kelimelerin yanlış yazımlarından, anlamlı kelimelerin esinlenilmiş hâllerinden, kısaltmalardan, argodan, klasik yapitlardan ve hatta opera eserlerinin karakterlerinden yaratılmıştır. Bu türden karakter isimleri, “yeni yüzyılın mitolojisi”nde dilin yapısökümüne ve yeni bir dil arayışına işaret etmektedir.

4 Çağımızın en ünlü sosyologlarından olan Zygmunt Bauman, bilgisayarlar vasıtasıyla kurulan Dünya Çapındaki Ağ’ın (World Wide Web) ortaya çıkışının, enformasyon söz konusu olduğunda "seyahat" (ve katedilecek "mesafe") kavramının kendisini geçersiz kıldığından yanı sıra enformasyonu hem teoride hem pratikte, bütün yerkürede aynı anda kullanılabilir hâle getirmiş olduğundan bahsetmektedir. (Zygmunt, 2012:21)

5 21. GIF Graphics Interchange Format'ın kısaltma olarak yazılışıdır. Türkçesi Grafik Değiştirme Biçimi olarak çevrilen GIF görüntüler, bilgisayar ortamında bir sayısal resim saklama biçimidir. Kayıpsız sıkıştırma kullanır. 8-bit renge (yani 256 renge) kadar destek verir ve 1-bit'lik (yani tek renk için) saydamlık sunar. JPEG ile birlikte bilgisayar dünyasında kullanılan en yaygın resim saklama biçimlerinden biridir. Genelde grafiklerin (az renk içermeleri dolayısıyla) saklanması için kullanılır. GIF, animasyonları küçük ve düşük çözünürlüklü film klipleri için kullanılabilir. Genel sınırlama dikkate alındığında 256 renkle GIF, genellikle dijital fotoğrafçılık için kullanılmaz. Dijital fotoğrafçılar görüntü dosyası formatları daha geniş bir dizi üretebilen TIFF, RAW veya JPEG gibi formatlar kullanır. PNG ve JPEG'den farklı olarak, GIF formatı piksel tabanlı animasyonların üretilmesine olanak tanır. https:// tr.wikipedia.org/wiki/Graphics_Interchange_Format Erişim: 06 Kasım 2015.

6 Daha detaylı bilgi için http://www.tate.org.uk/ whats-on/tate-britain/special-event/1840s-gif-party-callsubmissions linki ziyaret edilebilir (06.11.2015).

7 Zeynep Sayın’ın Sözlükçe’sinde imago'nun kapsamlı Latince tanımı şu şekildedir; “1. Görüntü, imge, suret. 2. Roma ölü tapı geleneğinde tahnitten önce cesedin yüzünden alınan ve Yunanlıları şaşırtan balmumu maske. Bir bakıma çifte bir varoluş. İsa'dan önce 2. yüzyılda Polybios, hayret içinde Romalıların cenaze törenini betimlemektedir. Forumdaki konuşmacı tribününde "herkesin görebilmesi için çoğu zaman ayakta duran” ceset, kendi yaşamını ve edimlerini metheden bir konuşma yapar. Ceset, ataların imago'larıyla çevrelenmiştir. Romalılara göre bir eikon olan imago, inanılmaz bir sadakatle ölünün yüzünü taklit eden bir tiyatro maskesi, prosopon ya da persona'dır. Genelde imago'lar, evlerde ahşap dolaplar içinde saklanır ve cenazelere eşlik eder. İlginçtir ki her Roma vatandaşının yalnızca bir kere gömülmesine karşın, Antonius döneminde imparator iki kere gömülür: Önce cesedi, sonra balmumu maskesi yakılır. Kaldı ki imparatorun cenaze törenine, ölü maskesi takmış ve ona öykünen bir oyuncu da katılır: Archemimus (Diodor, 31, 25). Oyuncu, sesiyle sözüyle imparatora öykünen bir ikizdir. 3. Aquinolu Thomas'a göre vestigium'un taşıyıcısı olan ahşap pano, boya vb." (Sayın, 2003:309-310)

\section{Kaynakça}

Baker, Ulus (2015). Sanat ve Arzu, ed: Tansu Açı, İstanbul: İletişim Yayınları.

Bauman, Zygmunt (2012). Küreselleşme: Toplumsal Sonuçları, çev: Abdullah Yılmaz, İstanbul: Ayrıntı Yayınları. 
Funk, Rainer (2009). Ben ve Biz: Postmodern İnsanın Psikanalizi, çev: Çağlar Tanyeri, İstanbul: Yapı Kredi Yayınları.

Pelevin, Viktor (2007). Dehşet Miğferi, çev: Dilek Şendil, İstanbul: Merkez Kitaplar.

Rancière, Jacques (2008). Görüntülerin Yazgısı: Duyulurun Paylaşımı, çev: Aziz Ufuk Kılıç, İstanbul: Versus Kitap.

Sayın, Zeynep (2000). “Batı'da ve Doğu'da Bedenin Temsilinde Haysiyet ve Zillet I".

Defter Dergisi 39: 159-204. (2003). İmgenin Pornografisi, İstanbul: Metis Yayınları.

\section{Görsel Kaynaklar}

Resim 1. John Brett, 'Lady with a Dove: Madame Loeser' (Güvercinli Kadın: Madame Loeser), 1864, Tate Müzesi, Londra, İngiltere.

Resim 2. Tate Müzesi'nde 7 Şubat 2014'de bir müze sergisi olarak kurgulanan etkinlikten bir fotoğraf. Resim 1'deki John Brett'in 'Lady with a Dove: Madame Loeser' (Güvercinli Kadın: Madame Loeser), adlı tablosunun James Kerr tarafından yapılmış GIF formatındaki replikası.

(http://tatecollectives.tumblr.com/post/73977089671/ james-kerr-aka-scorpion-daggers-remix-of-john) 